DOI: $10.7242 / 1998-2097 / 2018.1 .3$

УДК 579.64: 631.811.98

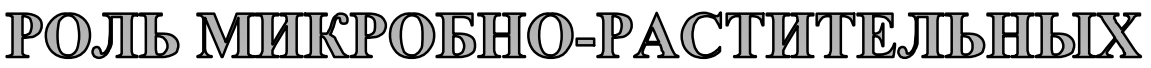

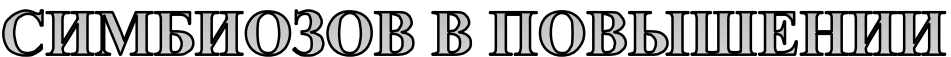

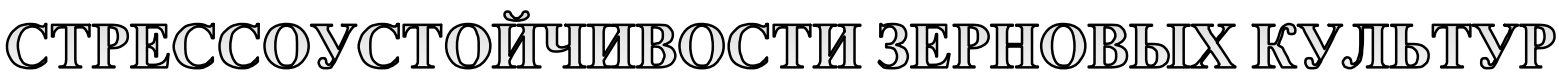

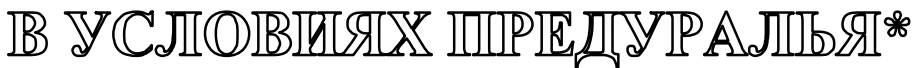

Н.П. Ковалевская, Институт экологии и генетики микроорганизмов УрО РАН

Д.Ю. Шаравин, Институт экологии и генетики микроорганизмов УрО РАН

Л.В. Бессонова, Пермский федеральный исследовательский центр УрО РАН

Ризосферные и эпифитные бактерии, изолированные из ризосферы растений засоленных почв Пермского края и с поверхности проростков зерновых культур, формируют ассоциации с сельскохозяйственными зерновыми культурами. Установлено, что активация механизмов холодоустойчивости озимых ржи, пшеницы, тритикале и солеустойчивости яровой пшеницы за счет повышения концентрации каротиноидов (антиоксидантная защита) регулируется ассоциативными бактериями. Внесение минеральных удобрений при посеве озимых зерновых культур приводит к качественному изменению состава ассоциативных бактерий, а также к снижению фотосинтетического потенциала пшеницы и тритикале после обработки гербицидами. При солевом стрессе на активацию антиоксидантной системы растений-хозяев (синтез каротиноидов) более значительное влияние оказывают ассоциативные солеустойчивые метилобактерии чем азотфиксирующие бактерии. Эпифитные галотолерантные бактерии (азотфиксирующие, нитратредуцирующие, денитрифицирующие) яровых злаковых культур (пшеница, овес, рожь) при повышении концентрации соли в почве проявляют фоссратсолюбилизирующую активность.

Ключевые слова: микробно-растительное взаимодействие, злаки, стрессоустойчивость, фотосинтетические пигменты, фитогормоньл.

В экономически развитых странах в конце XX века была сформулирована концепция адаптивного сельского хозяйства (sustainable agriculture), которая обеспечивает получение продукции путем использования биологических возможностей культивируемых организмов при минимальной антропогенной нагрузке на агроценозы. Одним из перспективных направлений повышения урожайности и качества зерна озимых и яровых культур является использование метаболического потенциала симбиотических бактерий.

Микробиомы растений представлены полифункциональными эндофитными и эпифитными (ризосферными) сообществами. Ризосферные и эндофитные микроорганизмы играют центральную роль в обеспечении жизнеспособности растений, способствуя усвоению и переработке питательных веществ, регулируя гормональный баланс, обеспечивая прямую или

\footnotetext{
* Работа выполнена в рамках государственного задания; номер госрегистрации темы: 01201353247.
} 
опосредованную защиту растений от вредных организмов (например фитопатогенов) и абиотических стрессов (обезвоживание, воздействие тяжелых металлов) и улучшая структуру почв.

Положительные результаты применения биологических препаратов в адаптивном земледелии, по-видимому, определяются высоким природным адаптационным потенциалом растительно-микробных ассоциаций и их эволюционно закрепленным взаимовыгодным сосуществованием. Бактерии в искусственно созданных ассоциациях с высшими растениями, микрогуматами и пестицидами на клеточном и организменном уровнях способны сохранять биохимическую активность. При этом поддерживается равновесие и биоразнообразие в микробном ценозе конкретной почвы или почвогрунта, корневая система растений обогащается агрономически полезными симбиотрофными микроорганизмами. Одновременно повышается активность обменных процессов в системе почва-растение, улучшается фитосанитарное состояние полей и грунтов теплиц.

Целью данного исследования является изучение воздействия ризосферных и эпифитных бактерий на формирование стрессоустойчивости и продуктивности разных сортов озимых и яровых зерновых культур в природно-климатических условиях Предуралья.

\section{Стрессоустойчивость озимых зерновых культур в условиях Предуралья}

Содержание фотосинтетических пигментов, их динамика и темпы накопления в течение вегетации в растениях служат важнейшей характеристикой продукционного процесса и фотосинтетической деятельности посевов сельскохозяйственных культур. Показано, что биологическая и хозяйственная урожайность у зерновых тесно коррелирует с хлорофильными фотосинтетическими потенциалами. В последнее десятилетие выявлено, что в результате селекции фотоэнергетический потенциал растений не увеличивается, а фактически остается на достигнутом в ходе эволюции уровне. И, очевидно, его возможностей в настоящее время уже не хватает, чтобы одновременно обеспечить получение высокого, качественного и стабильного урожая, так как для этого требуется значительно больше энергии, чем ее усваивают современные культурные растения [1]. Проведение целенаправленной работы по повышению фотоэнергетического потенциала сельскохозяйственных зерновых культур требует тщательного изучения стрессоустойчивости растений в различных природно-климатических зонах.

Исследования по стрессоустойчивости проводили с тремя озимыми зерновыми культурами: рожь, сорт Фаленская 4, пшеница, сорт Скипетр, тритикале, сорт Сирс. Полевые опыты закладывали по методике Б.А. Доспехова [3] на опытном поле Пермского НИИСХ. Ранее в исследованиях [5] было установлено, что у озимых зерновых растений в результате холодового закаливания происходит сдвиг температурного оптимума фотосинтеза в сторону более низких температур. Отмечено, что у адаптированных к холоду растений фотосинтетическая деятельность при температуре минус $5-9^{\circ} \mathrm{C}$ достигала $10-20 \%$ от таковой в оптимальных условиях выращивания. При изучении воздействия низких положительных температур на посевы озимых зерновых культур в начале весенней вегетации было установлено, что пшеница сорта Скипетр более холодоустойчивая, чем рожь сорта Фаленская 4 и тритикале сорта Сирс (табл. 1). В листьях озимой пшеницы содержание хлорофиллов $(a+b)$ было больше в 1,6 раза, чем в листьях ржи и тритикале; содержание каротиноидов в листьях пшеницы - в 1,73 и 1,28 раза - больше, чем в листьях ржи и тритикале.

Осеннее внесение удобрений под предпосевную культивацию привело, в сравнении с контрольными образцами, к снижению содержания хлорофиллов 
Таблиия 1

Содержание фотосинтетических пигментов в листьях озимых зерновых культур в условиях абиотических стрессов (мг/г сырой массы)

\begin{tabular}{|c|c|c|c|c|c|c|}
\hline \multirow{2}{*}{$\begin{array}{c}\text { Условия } \\
\text { выращивания }\end{array}$} & \multicolumn{3}{|c|}{ Хлорофиллы (а+в) } & \multicolumn{3}{|c|}{ Каротиноиды } \\
\hline & Рожь & Пшеница & Тритикале & Рожь & Пшеница & Тритикале \\
\hline \multicolumn{7}{|c|}{ Холодоустойчивость } \\
\hline Контроль & 0,512 & 0,841 & 0,524 & 0,485 & 0,837 & 0,653 \\
\hline $\begin{array}{l}\text { Удобрение, } \\
\text { \% от контроля }\end{array}$ & 100 & 94 & 74 & 104 & 120 & 57 \\
\hline \multicolumn{7}{|c|}{ Засухоустойчивость } \\
\hline Контроль & 0,766 & 1,160 & 1,938 & 0,398 & 0,540 & 0,648 \\
\hline $\begin{array}{l}\text { Удобрение, } \\
\text { \% от контроля }\end{array}$ & 166 & 244 & 99 & 108 & 87 & 74 \\
\hline \multicolumn{7}{|c|}{ Гербицидоустойчивость } \\
\hline Контроль & 0,979 & 2,164 & 1,742 & 0,241 & 0,476 & 0,562 \\
\hline $\begin{array}{l}\text { Удобрение, } \\
\text { \% от контроля }\end{array}$ & 129 & 41 & 41 & 146 & 90 & 37 \\
\hline
\end{tabular}

$(a+b)$ в листьях пшеницы на $6 \%$, в листьях тритикале - на $26 \%$. У растений пшеницы происходило увеличение количества каротиноидов, а в листьях тритикале было отмечено снижение каротиноидов, что составило $120 \%$ и $57 \%$.

В условиях прогрессирующей почвенной засухи в мае 2016 г. среди исследованных озимых зерновых культур наиболее интенсивный синтез хлорофиллов и каротиноидов был зафиксирован в листьях тритикале (см. табл. 1). Внесение минеральных удобрений повышало интенсивность синтеза хлорофиллов в листьях ржи (166\%) и пшеницы $(244 \%)$ и снижало синтез каротиноидов у пшеницы $(87 \%)$ и тритикале (74\%).

Изучение влияния гербицидов на интенсивность фотосинтеза озимых зерновых культур показало, что наиболее адаптированной к гербицидам была озимая пшеница, в листьях которой через 3 дня после стрессового воздействия содержание хлорофиллов было выше, чем в листьях ржи и тритикале, в 2,21 и 1,24 раза, соответственно (см. табл. 1). В конце фазы кущения озимых культур содержание каротиноидов в листьях значительно понизилось у ржи (20\% от общего содержания фотосинтетических пигментов), пшеницы (18\%) и тритикале $(24 \%)$.

Внесение минеральных удобрений под посевы привело к снижению интенсивности фотосинтеза озимой пшеницы и тритикале при гербицидной обработке: содержание хлорофиллов $a+b$ снизилось до $41 \%$, происходило также ингибирование синтеза каротиноидов. Однако в листьях ржи наблюдалось повышение содержания хлорофиллов (129\%) и каротиноидов (146\%). Известно, что минеральные удобрения обладают «физиологической» кислотностью. Повышенная кислотность почвы ингибирует деятельность естественного азотфиксирующего микробоценоза, а также усиливает деятельность некоторых фитопаразитов. Кроме того, способностью разрушать органические ксенобиотики (пестициды, гербициды и др.) обладают не только почвенные и ризосферные микроорганизмы, но и эндофитные бактерии [2]. Установлено, что в присутствии определенных поллютантов кодирующие деградацию этих веществ гены встречаются в эндофитных бактериях в несколько раз чаще, чем в почвенных бактериях. При сопоставлении динамики содержания зеленых и желтых пигментов во флаговых листьях озимых зерновых культур в течение весенне-летней вегетации, а также на основании литературных данных было выдвинуто предположение об активном участии ассоциативных бактерий в регуляции интенсивности фотосинтеза зерновых культур при разных типах стресса. 


\section{Биорегуляторная активность ризосферных бактерий}

В стрессовых условиях растения нуждаются в поступлении дополнительных регуляторов роста, таких как фитогормоны и витамины, источником которых также могут быть микроорганизмы ризосферы и филлосферы. Поиск симбиотических бактерий, контролирующих развитие растений в условиях абиотических стрессов остается актуальным. С этой целью было проведено изучение влияния инокуляции ауксинсинтезирующими солеустойчивыми микроорганизмами на синтез фотосинтетических пигментов в онтогенезе и морфометрические характеристики проростков мягкой яровой пшеницы (Triticum aestivum L.) сорта Горноуральская в условиях солевого стресса.

С территории техногенных полигонов Верхнекамского месторождения калийных солей были отобраны галофитные растения, с поверхности которых выделены изоляты солеустойчивых бактерий. Среди бактериальных изолятов способностью к синтезу фитогормона индолил-3уксусной кислоты (ИУК) при выращивании на солевой среде $(50,0$ г/л $\mathrm{NaCl})$ с добавлением пирувата $(1,0$ г/л) и триптофана (200 мкг/мл) обладали два штамма галотолерантных азотфиксирующих бактерий Pantoea vagans A1 (KP115326) и Pantoea vagans A15 (КМ235113), изолированные с поверхности солеустойчивых растений Осота полевого (Sonchus arvensis L.) и Клевера лугового (Trifolium pratense L.). Направленность происходящих изменений в онтогенезе пшеницы зависела от конкретной бактерии-продуцента ИУК и времени инкубации. Наибо- лее выраженное комплексное воздействие ассоциативных бактерий на развитие корней и побегов пшеницы было отмечено на 6-е сутки одновременно с максимумом синтеза фитогормона индолил-3-уксусной кислоты бактериями P. vagans A1 и P. vagans A15, 64 и 43 мкг/мл (табл. 2). При периодическом культивировании на синтетической среде бактерий $P$. vagans $\mathrm{A} 1$ и $P$. vagans $\mathrm{A} 15$ в присутствии $1 \% \mathrm{NaCl}$ на 6 сутки снижался микробный синтез ИУК на $23 \%$ и $19 \%$, соответственно.

Изучение динамики содержания хлорофиллов и каротиноидов в проростках пшеницы в условиях натрий-хлоридного засоления почвы показало, что наиболее высокое содержание хлорофиллов при 0,5\%-ном $\mathrm{NaCl}$ было зафиксировано при симбиозе растения с бактериями $P$. vagans A15 на 3-е сутки $(272 \%)$, а для $P$. vagans A1 - на 6-е сутки (241\%).

Отмечено, что на 6-е сутки при 0,5\%-ном содержании $\mathrm{NaCl}$ бактерии $P$. vagans A15 уже не снижали токсическое действие хлорида натрия на синтез фотосинтетических пигментов, в листьях пшеницы снижалось содержание хлорофиллов до $53 \%$ (\%, от контроля) и каротиноидов $-33 \%$. Повышение в почве солевой концентрации до $1 \% \mathrm{NaCl}$ уже через 6 суток приводило к полному ингибированию биосинтеза фотосинтетических пигментов в проростках пшеницы.

Из ризосферы солеустойчивых растений Сведа стелющаяся (Suaeda prostrate Pallas) и Подорожник морской (Plantago maritime L.) были выделены галотолерантные метилотрофные бактерии Methylophaga nitratireducenticrescens M1K (KM192265) и Paracoccus sp. M7 (КМ192266). В отличие от галотолерант-

Таблицуа 2

Образование фитогормона индолил-3-уксусной кислоты ассоциативными галотолерантными бактериями на синтетической среде при периодическом культивировании на 6 сутки (мкг/мл)

\begin{tabular}{|c|c|c|c|c|}
\hline Штамм & $\begin{array}{c}\text { Pantoea } \\
\text { vagans A1 }\end{array}$ & $\begin{array}{c}\text { Pantoea } \\
\text { vagans A15 }\end{array}$ & $\begin{array}{c}\text { Methylophaga } \\
\text { nitratireducenticrescens M1K }\end{array}$ & $\begin{array}{c}\text { Paracoccus sp. } \\
\text { M7 }\end{array}$ \\
\hline $0 \% \mathrm{NaCl}$ & 64 & 43 & 7 & 2 \\
\hline $1 \% \mathrm{NaCl}$ & 49 & 35 & 10 & 5 \\
\hline
\end{tabular}


ных азотфиксирующих бактерий, на третий день после инокуляции метилотрофными бактериями М1К и М7 проростков яровой пшеницы при $1 \% \mathrm{NaCl}$, в сравнении с необработанными образцами, наблюдалось увеличение длины проростков (290 и $180 \%)$ и корней (314 и $229 \%)$. Кроме того, происходило увеличение массы проростков (492 и 329\%) и корней (933\% и 650\%). В вариантах с метилотрофами М1К и $\mathrm{M} 7$ при $1 \% \mathrm{NaCl}$ на пятый день эксперимента было зафиксировано увеличение содержания хлорофиллов (190\% и $245 \%$ от контроля). Биосинтез каротиноидов (антиоксидантная защита) в листьях яровой пшеницы увеличивался в присутствии М1К и М7 в 6,7 и 7,5 раз соответственно.

В эксперименте было установлено, что в присутствии $1 \% \mathrm{NaCl}$ метилобактерии М1К и М7 синтезируют фитогормон ауксин в 1,4 (10 мкг/мл) и 2,5 (5 мкг/мл) раз больше, чем в вариантах без соли (см. табл. 2).

В результате проведенных исследований было показано, что культуры галотолерантных азотфиксирующих бактерий синтезируют ИУК до 140 мкг/мл, а метилотрофные бактерии не более 10 мкг/мл. Повышение концентрации соли в среде от 0,5 до $1,0 \%$ приводит к ингибированию синтеза ауксина у галотолерантных азотфиксирующих бактерий, но активируется синтез фитогормона у галотолерантных метилобактерий. При солевом стрессе на активацию антиоксидантной системы растений-хозяев (синтез каротиноидов) более значительное влияние оказывают ассоциативные солеустойчивые метилобактерии чем азотфиксирующие бактерии.

\section{Применение ассоциативных бактерий в агротехнологии как стимуляторов роста пшеницы}

Растения в ходе окультуривания и селекции в значительной степени утратили способность адаптироваться к неблагоприятным условиям среды. Адап- тивные функции микробно-растительных симбиозов особенно ярко проявляются в отношении питания азотом и фосфором, основные запасы которых в почве находятся в составе высокомолекулярных соединений, недоступных для ассимиляции корнями. Потребности растений в азоте более чем на $2 / 3$ обеспечиваются за счет универсальных симбионтов высших растений - ростстимулирующих бактерий (PGPB) (plant growth_promoting bacteria) [4].

С листовой поверхности озимых злаковых культур (пшеница - 9 сортов, рожь - 9 сортов, тритикале - 7 сортов) проведено выделение бактерий, синтезирующих фитогормоны ауксины. В августе 2016 года на экспериментальных полях Пермского сельскохозяйственного института начаты совместные исследования по изучению влияния ассоциативных синтезирующих ауксин бактерий на повышение адаптивных возможностей разных сортов озимой пшеницы на стадии осеннего и весеннего кущения к низким температурам. Показано, что обработка посевного зерна препаратами эпифитных бактерий, выделенных с листовой поверхности проростков озимой пшеницы разных сортов (Башкирская 10, Бирюза, Московская 39) приводит на стадии осеннего кущения к повышению продукции низкомолекулярных антиоксидантов (каротиноиды, аскорбиновая кислота, антоцианы) при понижении температуры ниже $1{ }^{\circ} \mathrm{C}$. Отмечено, что у инокулированных бактериями 50-дневных проростков пшеницы высокое содержание каротиноидов в листьях сохраняется более 10 суток при колебании отрицательных температур от $-4^{\circ} \mathrm{C}$ до $-1^{\circ} \mathrm{C}$.

На примере самых активных из известных в литературе штаммов показано, что наиболее эффективно высвобождают фосфаты бактериальные штаммы, стехиометрически окисляющие глюкозу до глюконовой и кетоглюконовой кислот. При этом глюкоза сначала полностью окисляется в эти кислоты, которые вызывают растворение фосфатов и начинают 
усваиваться микроорганизмами только после окисления всей глюкозы в среде. С листовой поверхности проростков яровых злаковых культур (пшеница, овес, рожь) были выделены ассоциативные галотолерантные азотфиксирующие, нитратредуцирующие и денитрифицирующие бактерии.

Периодическое культивирование бактерий на среде «Г» с гидроксиапатитом (19 мМ, рН среды 7,9) показало, что на протяжении 10 суток во всех культурах отмечено снижение $\mathrm{pH}$ среды до 6,303,85 . Спектрофотометрическое определение растворимых в воде фосфатов свидетельствовало о том, что уже через 3 суток все исследуемые штаммы проявляли фосфатсолюбилизирующую активность (рисунок). Установлено, что процесс солюбилизации фосфатов ассоциативными галотолерантными бактериями - симбион- тами ржи - происходит интенсивнее, чем у симбионтов пшеницы. За 4 суток наибольшее извлечение растворимых форм фосфора в среде с гидроксиапатитом составило 24,5\% (азотфиксаторы - рожь), а наименьшее - 5\% (азотфиксаторы - пшеница). На протяжении всего эксперимента ни у одной из культур не удалось обнаружить синтеза ИУК.

В настоящее время в полевых условиях проводятся эксперименты по изучению влияния ростстимулирующих бактерий на повышение фотосинтетического потенциала и продуктивности разных сортов озимой и яровой пшеницы на дерново-подзолистой почве Пермского края. Результаты проводимых исследований будут использованы для разработки адаптивных агротехнологий выращивания зерновых культур в Предуралье.

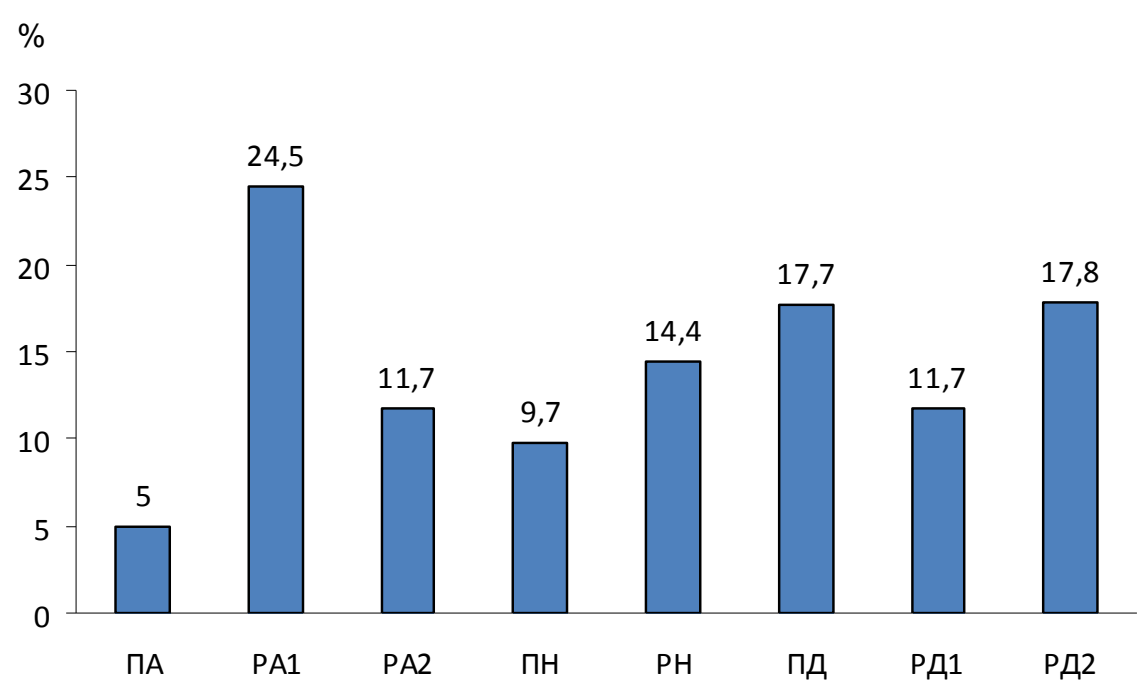

Рис. Фосфатсолюбилизирующая активность галотолерантных бактерий, ассоциированных с представителями семейства Роасеае.

ПА, РА-азотфиксирующие бактерии пшеницы и ржи; ПН, РН - нитратредуцирующче, ПД, РД - денитрифищирующче

\section{Библиографический список}

1. Амелин А.В., Чекалин Е.И. Селекция на повышение фотоэнергетического потенциала растений и эффективности его использования, как стратегическая задача в обеспечении импортозамещения и продовольственной безопасности России // Вестн. Орловского гос. аграрного ун-та. - 2015. Т. 57. - № 6. - С. 9-17.

2. Гарипова С.P. Перспективы использования эндофитных бактерий в биоремедиации почв агроэкосистем от пестицидов и других ксенобиотиков // Успехи современной биологии. - 2014. T. 134. - № 1. - С. 35-47.

3. Доспехов Б.А. Методика полевого опыта. - М.: Колос, 1985. - 351 с. 
4. Иванчина Н.B., Гарипова С.P. Влияние ростстимулирующих бактерий (PGPB) на продуктивность и устойчивость растений // Агрохимия. - 2012. - № 7. - С. 87-95.

5. Пешкова А.А., Дорофеев Н.В. Адаптация фотосинтетического аппарата озимой пшеницы в период осеннего развития // Вестник ИрГСХА. - 2011. - № 45. - С. 20-27.

\title{
THE ROLE OF PLANT-MICROBE SYMBIOSES IN INCREASING STRESS TOLERANCE OF CEREAL CROPS IN THE CIS-URAL REGION
}

\author{
N.P. Kovalevskaya, D.Y. Sharavin, L.V. Bessonova \\ Institute of Ecology and Genetics of Microorganisms UB RAS
}

Rhizosphere and epiphytic bacteria isolated from the saline soils of the Perm region and also from the surface of cereal crops seedlings are able to form associations with agricultural crops. It is established that the activation of the mechanisms of cold resistance of winter rye, wheat, triticale and salt tolerance of spring wheat by increasing of carotenoid concentration is regulated by associative bacteria. Application of mineral presowing treatment of winter crops leads to qualitative changes in associative bacteria composition and also reduces photosynthetic potential of wheat and triticale after herbicides treatment. Associative methylobacteria under salt stress have major impact on host plant antioxidant system activation (synthesis of carotenoids) than nitrogen-fixing bacteria. Epiphytic halotolerant nitrogen-fixing, nitrate-reducing and denitrifying bacteria of spring cereals (wheat, oat, rye) exhibiting phosphate solubilizing activity under salt stress in the soil.

Keywords: plant-microbe interaction, cereal crops, stress tolerance, photosynthetic pigments, phytohormones.

\section{Сведения об авторах}

Ковалевская Нина Петровна, кандидат биологических наук, младший научный сотрудник, Институт экологии и генетики микроорганизмов УрО РАН - филиал Пермского федерального исследовательского центра УрО РАН (ИЭГМ УрО РАН), 614081, г. Пермь, ул. Голева, 13; e-mail: nina_kov@mail.ru

Шаравин Дмитрий Юрьевич, кандидат биологических наук, инженер, ИЭГМ УрО РАН; e-mail: dima-sharavin@yandex.ru

Бессонова Людмила Владимировна, старший научный сотрудник лаборатории семеноводства, Пермский федеральный исследовательский центр УрО РАН (ПФИЦ УрО РАН), 614532, Пермский край, с. Лобаново, ул. Культуры, 12; e-mail: 888bessonova@mail.ru 


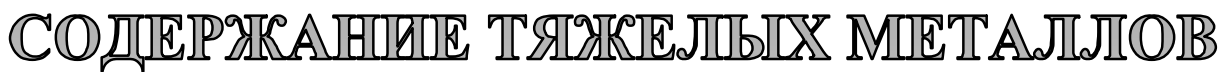

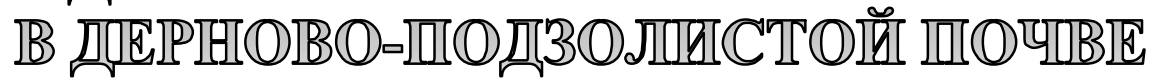

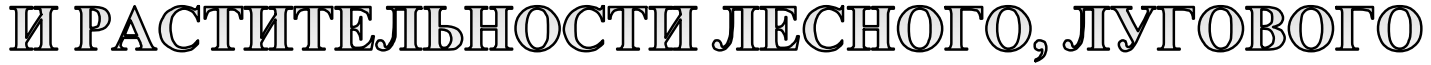

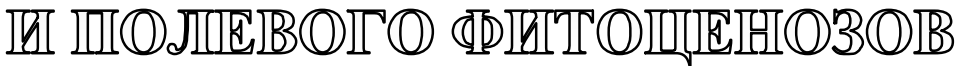

Н.Е. Завьялова, Пермский научно-исследовательский институт сельского хозяйства

К.Н. Корляков, Пермский научно-исследовательский институт сельского хозяйства

Содержание солей тяжелых металлов (меди, цинка, кадмия и свинца) определялось в почве и растительности лесного, лугового и полевого фритоценозов, расположенных на территории опытного поля Пермского НИИСХ. Исследования производились в течение 2012-2014 гг. Почва во всех изучаемых фритоценозах - дерново-подзолистая, с разной степенью выраженности подзолистого процесса. Изучаемый растительный материал: хвоя и листва деревьев, травостой естественного злаково-разнотравного луга, зеленая масса козлятника восточного.

Содержание тяжелых металлов в почве и растениях всех фритоценозов было значительно ниже ПДК, за исключением содержания меди в лесном фритоценозе, расположенном на расстоянии 100-200 м от фредеральной автомобильной дороги. Концентрация меди и цинка возрастала со временем: в 2014 году содержание меди и цинка по сравнению с 2012 годом увеличилось соответственно в 3 и 2 раза. Содержание свинца существенно не изменилось и было значительно ниже ПДК для всех изучаемых фитоценозов. Тенденция к некоторому увеличению содержания тяжелых металлов в почве и растительности не может служить препятствием для проведения научных исследований на изучаемых участках.

Ключевые слова: лесной фиточеноз, луговой фиточеноз, севооборот, содержание тяжельх металлов.

Почва - главное средство сельскохозяйственного производства и основа агроэкосистем. Растения получают из почвы до 95\% всех элементов питания, поэтому забота о сохранении почвенного плодородия является одной из приоритетных в сельском хозяйстве. Основным условием стабильного развития агроценозов и фитоценозов является сохранение, воспроизводство и рациональное использование плодородия земель.

Природные экологические системы обладают свойством саморегуляции и являются стабилизаторами природной среды при условии отсутствия вмешательства человека. Искусственные агроэкосистемы, наоборот, нуждаются в постоянном контроле и поддержании их в стабильном состоянии. Анализ литературных источников указывает на то, что дерново-подзолистые почвы, формирующиеся в различных фитоценозах, существенно отличаются по кислотности среды, количеству и качеству гумуса, содержанию 